\title{
Screening and Partial Purification of L-Asparaginase from the Bacteria Isolated from Soil Samples
}

\author{
A.V. Savani ${ }^{1}$ and P.R. Parmar ${ }^{2 *}$ \\ ${ }^{1}$ C. G. Bhakta Institute of Biotechnology, Uka Tarsadia University, \\ Tarsadi, Surat - 394 350, Gujarat, India \\ ${ }^{2}$ Main Cotton Research Station, Navsari Agricultural University, Surat - 395 007, Gujarat, India \\ *Corresponding author
}

\section{A B S T R A C T}

K e y w o r d s
Isolation,
L-asparaginase,
Partial purification,
Soil samples,
Bacillus.
Article Info
Accepted:
14 July 2017
Available Online:
10 September 2017

L-asparaginase producing bacteria were isolated from the selected soil samples from different location of Surat district, Gujarat. The primary screening using rapid plate assay determined that out of 120 isolates, 33 strains were producing L-asparaginase. Among 33 L-Asparaginase Producing Bacterial strains (APB), significant pink color zone were observed in APB2 $(0.8 \mathrm{~mm})$, APB1 $(0.9 \mathrm{~mm})$, APB28 $(0.9 \mathrm{~mm})$ and APB26 $(1.2 \mathrm{~mm})$ at $72 \mathrm{hrs}$. Further, these four isolates preliminary screened for fermentation at laboratory level by observing $\mathrm{pH}$, biomass and crude enzyme activity. Among four isolates, APB26 produced substantial L-asparaginase $(3.78 \mathrm{unit} / \mathrm{ml})$ followed by APB1 (1.58 unit/ml), APB2 (1.08 unit/ml) and APB28 (0.80 unit/ml) within $72 \mathrm{hrs}$. Further, the attempt was made to optimize $\mathrm{pH}$ and temperature on L-asparaginase production by APB26 within 72 hrs. The results showed that $\mathrm{pH} 7.0$ and $37^{\circ} \mathrm{C}$ temperature was optimum. Partial purification with ammonium sulfate precipitation showed 2.59 units/ml specific activity with $89.3 \%$ yield and 1.16 purification fold while, DEAE cellulose chromatography given 3.57 unit/ml specific activity with $66.3 \%$ yield and 1.60 purification fold. Based on morphological, cultural and biochemical test, APB26 was tentatively identified as Bacillus species.

\section{Introduction}

Enzymes are the selective proteins with high specificity that catalyze all the metabolic reactions in living organisms. Millions of enzymes are produced by prokaryotic and eukaryotic organisms. Use of microbial enzymes as drugs is an important research in the field of pharmaceutical industries. One of the most important discovery in this field is an enzyme L-asparaginase discovered by Clementi in 1922 in serum of guinea pig. Lasparaginase is more promising in the treatments of Hodgkin disease, acute myelocytic leukemia, acute myelomonocytic leukemia, chronic lymphocytic leukemia, lymphosarcoma treatment, reticulosarbom and melanosarcoma (Oettgen, 1967). Administration of guinea pig serum into mice suffered from lymphomas shown regression against cancerous cells was studied by Kidd in 1953. After that, Broome in 1968 conclude the anti-lymphatic activity guinea pig serum was due to L-asparaginase. Partial purification of L-asparaginase from guinea pig sera was carried out by Yellin and 
Wriston (1966) but after extraction, insufficient quantity of enzyme boost researcher on microbial source for higher production of L-asparaginase from Escherichia coli. It has shown same tumoricidal activity as guinea pig sera. Due to broad diversity, easy to production, recovery and especially its susceptibility towards genetic manipulation for higher production of enzymes, microbes was found to be best alternative for L-asparaginase production. Numerous bacterial species viz., Escherichia (Warangkar et al., 2010), Aerobacter, Erwinia, Serratia (Agarwal et al., 2011), Xanthomonas (Abbas et al., 2010), Bacillus was reported to produce L-asparaginase (Pradhan et al., 2013; Sunitha et al., 2010; Thenmozhi et al., 2011). The present investigation carried out with isolation and screening of L-asparaginase producing bacteria from diversified soil samples, fermentation studies, partial purification of Lasparaginase from potential isolates and preliminary microbial characterization of the isolates.

\section{Materials and Methods}

\section{Sample collection}

Soil samples collected from the different location of Surat district of Gujarat. Seven different diversified sites (Table 1) were selected to collect the soil samples. Samples were stored in the clean sterile glass bottles and stored at $4{ }^{\circ} \mathrm{C}$.

Isolation and primary screening of Lasparaginase producing bacteria

To isolate L-asparaginase producing bacteria, $10 \mathrm{~g}$ of each soil samples were inoculated into $100 \mathrm{ml}$ of sterile modified M9 broth $(\mathrm{g} / \mathrm{l})(2.0$

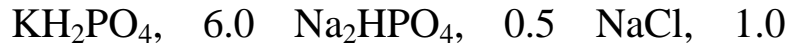
$\mathrm{MgSO}_{4} .7 \mathrm{H}_{2} \mathrm{O}, 1.0 \mathrm{CaCl}_{2} .2 \mathrm{H}_{2} \mathrm{O}, 3.0$ glucose and 6.0 asparagine, $\mathrm{pH} 7.2 \pm 0.2$ ) and incubated at $30^{\circ} \mathrm{C}$ for $48-72 \mathrm{hrs}$ (Bhat et al.,
2015). Each enriched samples were diluted in the range of $10^{-2}$ to $10^{-8}$ and $0.1 \mathrm{ml}$ of diluents was spread on modified sterile M-9 agar medium containing $0.005 \%$ phenol red dye and kept at room temperature. Each bacterial colony was picked from the plates and was streaked using quadrate method on nutrient media to get pure culture of bacteria. Pure cultures were preserved on nutrient agar slants at $4^{\circ} \mathrm{C}$. Primary screening of Lasparaginase producing bacteria was performed by rapid plate assay (Gulati et al., 1997). For that, each bacterial colony was spot inoculated on modified M-9 agar medium containing $0.005 \%$ phenol red dye and kept at room temperature for three to four days. Plates without L-asparagine (use of $\mathrm{NaNO}_{3}$ as nitrogen source) and without dye were used as controls (Jimat et al., 2015). Lasparaginase producing strains were screened based on wide formation of pink zone around the colonies on plates and used for further studies.

\section{Inoculums preparation and L-asparaginase production by isolates}

The potential bacterial strains showing large pink halos in rapid plate assay inoculated into $5.0 \mathrm{ml}$ of sterile nutrient medium. It was incubated at $37^{\circ} \mathrm{C}$ for $24 \mathrm{hrs}$. Each inoculums (O.D. 0.8 \pm 0.2 ) were suspended into $100 \mathrm{ml}$ of sterile modified M-9 medium ( $\mathrm{pH} 7.0 \pm 0.2$ ) in $250 \mathrm{ml}$ Erlenmeyer flasks and kept at $120 \mathrm{rpm}$ for three days along with its control. The uninoculated medium was used as a control. Further, $10 \mathrm{ml}$ of culture broth was withdrawn after 24, 48 and $72 \mathrm{hrs}$ and used to determine $\mathrm{pH}$, bacterial biomass and crude enzyme activity (Jimat et al., 2015). Each procedure was performed in triplicate.

\section{L-asparaginase assay}

To perform L-asparaginase assay, $5.0 \mathrm{ml}$ of culture broth was centrifuged at $10000 \mathrm{rpm}$ for 5 minutes. The $0.1 \mathrm{ml}$ of crude enzyme 
(supernatant) was mixed with $0.2 \mathrm{ml}$ of 0.05 $\mathrm{M}$ Tris- $\mathrm{HCl}(\mathrm{pH} 8.6)$ and $1.7 \mathrm{ml}$ of $\mathrm{L}-$ asparagine $(0.01 \mathrm{M})$. After incubation of 10 minutes, reaction was stopped using $0.5 \mathrm{ml}$ of 1.5 M trichloroacetic acid. To obtain clear solution, it was centrifuged at $10000 \mathrm{rpm}$ for 5 minutes. Further, $0.5 \mathrm{ml}$ of supernatant was diluted upto $7.0 \mathrm{ml}$ using distilled water in a separate tube. It was treated with $1 \mathrm{ml}$ of Nessler's reagent. Color development after 15 minutes was observed using absorbance at $480 \mathrm{~nm}$. L-asparaginase activity of each sample was determined using standard curve of ammonia. One international unit (IU) of Lasparaginase was defined as amount of enzyme that liberates one $\mu$ mole of ammonia per minute under the assay condition (Worthington, 2007).

\section{Determination of protein, biomass and $\mathrm{pH}$}

Estimation of protein was carried out using Lowry method (1951). For that, one $\mathrm{ml}$ of crude extract was mixed with one ml of $0.1 \mathrm{~N}$ $\mathrm{NaOH}$ solution followed by $5.0 \mathrm{ml}$ of copper reagent. After, 10 minutes incubation at room temperature, $0.8 \mathrm{ml}$ of Folin-Ciocalteu reagent was added and kept for 30 minutes. Absorbance was measured at $660 \mathrm{~nm}$ using spectrophotometer. Standard protein assay was in the range of $10-120(\mu \mathrm{g} / \mathrm{ml})$ concentration using bovine serum albumin. Bacterial biomass and $\mathrm{pH}$ was measured using spectrophotometer $(600 \mathrm{~nm})$ and $\mathrm{pH}$ electrode, respectively.

\section{Effect of $\mathrm{pH}$ and temperature on enzyme production}

To study the optimum $\mathrm{pH}$, culturing the strain in production medium with $\mathrm{pH}$ range of 4.0 to 8.0 was performed. The optimal $\mathrm{pH}$ was used for subsequent study. To determine the optimum temperature, production medium was kept at different temperatures $25^{\circ} \mathrm{C}$, $37^{\circ} \mathrm{C}, 45^{\circ} \mathrm{C}$ and $55^{\circ} \mathrm{C}$ for 72 hours was carried out (Varma et al., 2016). Strains that showed significant production of enzyme was used for further study.

\section{Partial purification of $\mathrm{L}$-asparaginase from the potential isolates}

\section{Ammonium sulfate precipitation}

Crude enzyme was subjected to saturate with $45 \%$ of ammonium sulfate $(\mathrm{pH} \mathrm{8.5)}$. Each saturated sample was kept at $4^{\circ} \mathrm{C}$ temperature overnight. After incubation, saturated samples were centrifuged at $10,000 \mathrm{rpm}$ for 5 minutes. Supernatant subjected to $80 \%$ saturation with ammonium sulfate and centrifuged at 7000 $\mathrm{rpm}$ for 10 minutes at $4^{\circ} \mathrm{C}$. The collected precipitates subjected to dialysis into pretreated buffered dialysis bag. After dialysis, the samples were used for enzyme activity and protein estimation (Dhevagi and Poorani, 2006).

\section{DEAE cellulose chromatography}

DEAE cellulose column was pre-equilibrated with $50 \mathrm{mM}$ Tris- $\mathrm{HCl}(\mathrm{pH} 8.5)$ containing $100 \mathrm{mM} \mathrm{KCl}$ was loaded with $5 \mathrm{ml}$ of crude enzyme. The column was washed with twocolumn volume of the above buffer and adsorbed protein was eluted using $50 \mathrm{mM}$ Tris-HCl buffer ( $\mathrm{pH} 8.5$ ). Fractions obtained were analyzed for enzyme activity (Emmanuel et al., 2015).

\section{Preliminary characteristics of potential bacteria}

Preliminary microbiological characters like morphological (Gram reaction, capsule and spore staining); cultural (colony characters on Nutrient agar, MacConkey's agar, Tributyrene agar and Blood agar) and biochemical tests (Hydrolysis of starch, casein and gelatin, nitrate reduction, citrate utilization, IMViC test, phenlyalanie 
deaminase, oxidase, catalase and utilization of lactose, maltose, sucrose, glucose, xylose, manose, mannitol and fructose) were performed using standard microbiological methods (MacFaddin, 2000).

\section{Results and Discussion}

Primary screening of L-asparaginase producing bacteria and determination of enzyme activity

Total 120 distinct bacterial colonies were isolated from organic and polluted soil samples collected from the different locations of Surat, Gujarat. Based on rapid plate assay, it was observed that among 120 isolates, 33 bacterial strains showed pink color zones on modified M-9 medium for L-asparaginase production. The isolates produced zones in the range of 0.1 to $1.2 \mathrm{~mm}$ in diameter within 72 hrs. Four L-asparaginase producing bacterial (APB) isolates viz; APB 26 (1.2 $\mathrm{mm}), \mathrm{APB} 1$ and APB 28 (0.9 mm) and APB 2 $(0.8 \mathrm{~mm})$ showed significant zone of index and other did not show reproducible results (Table 2). Thus, these four isolates were used for primary fermentation study at laboratory scale level.

Fermentation was performed by inoculating APB1, APB2, APB26 and APB28 bacteria strains into the modified M-9 medium. At specific time interval of 24,48 and $72 \mathrm{hrs,}$ samples were analyzed for biomass, $\mathrm{pH}$ and ammonia production. Data (Table 3) showed that the biomass, $\mathrm{pH}$ and enzyme unit were increasing with 24,48 and 72 hours with all the four bacterial isolates. However, bacterial isolate APB26 gave maximum enzyme activity of 3.78 unit/ml within 72 hrs. All other isolates were found to produce less enzyme activity than APB26. Hence, an isolate APB26 was used for further study.

Effect of pH and temperature on production of L-asparaginase and partial purification

Study of effect of different $\mathrm{pH}$ and temperature were performed on production of L-asparaginase produced by APB26. Maximum activity of enzyme was found with $\mathrm{pH} 7.0$ (4.20 units/ml) followed by $\mathrm{pH} 8.0$ (2.50 units/ml) within 72 hrs. Decreased or inhibitory enzyme activity found with too acidic and alkaline condition. Data showed maximum activity of L-asparaginase at $37^{\circ} \mathrm{C}$ $(5.40$ units $/ \mathrm{ml})$ followed by $25^{\circ} \mathrm{C} \quad(3.50$ units/ml). Higher temperature was found to be inhibitory on production of enzyme (Figure $1)$.

Partial purification of L-asparaginase produced by strain APB26 was performed by two steps; ammonium sulfate precipitation followed by its dialysis and DEAE cellulose chromatography.

Table.1 Soil samples collected from different locations of Surat district, Gujarat

\begin{tabular}{|c|l|l|}
\hline Sr. No. & \multicolumn{1}{|c|}{ Soil samples } & \multicolumn{1}{c|}{ Location } \\
\hline 1 & Sugarcane rhizosphere soil & Tarsadi, Bardoli \\
\hline 2 & Tulsi rhizosphere soil & Garden of Tarsadi, Bardoli \\
\hline 3 & Rice rhizosphere soil & Tarsadi, Bardoli \\
\hline 4 & Soil from poultry farm & Poultry farm, Tarsadi \\
\hline 5 & Soil treated with compost & Bamroli, Bardoli \\
\hline 6 & $\begin{array}{l}\text { Soil from the farm located nearby } \\
\text { industrial area }\end{array}$ & Jolwa, Surat \\
\hline 7 & Soil enriched with oil from garage & Amroli, Surat \\
\hline
\end{tabular}


Table.2 Qualitative data of L-asparaginase production during primary screening

\begin{tabular}{|c|c|c|c|c|c|c|c|c|c|}
\hline \multirow{2}{*}{$\begin{array}{l}\text { Sr. } \\
\text { No. }\end{array}$} & \multirow{2}{*}{$\begin{array}{c}\text { Isolate } \\
\text { No. }\end{array}$} & \multicolumn{3}{|c|}{ Zone Index (mm) } & \multirow{2}{*}{$\begin{array}{l}\text { Sr. } \\
\text { No. }\end{array}$} & \multirow{2}{*}{$\begin{array}{c}\text { Isolate } \\
\text { No. }\end{array}$} & \multicolumn{3}{|c|}{ Zone Index (mm) } \\
\hline & & $\begin{array}{c}24 \\
\text { hrs. }\end{array}$ & 42 hrs. & 72 hrs. & & & 24 hrs. & 42 hrs. & $\begin{array}{c}72 \\
\text { hrs. }\end{array}$ \\
\hline 1. & APB1 & 0.6 & 0.7 & 0.9 & 18. & APB 18 & 0.3 & 0.3 & 0.3 \\
\hline 2. & APB2 & 0.5 & 0.6 & 0.8 & 19. & APB19 & 0.2 & 0.4 & 0.4 \\
\hline 3. & APB3 & 0.1 & 0.2 & 0.3 & 20. & APB20 & 0.1 & 0.2 & 0.2 \\
\hline 4. & APB4 & 0.2 & 0.3 & 0.4 & 21. & APB21 & 0.0 & 0.0 & 0.1 \\
\hline 5. & APB5 & 0.1 & 0.2 & 0.4 & 22. & APB22 & 0.1 & 0.1 & 0.1 \\
\hline 6. & APB6 & 0.3 & 0.4 & 0.4 & 23. & APB23 & 0.0 & 0.0 & 0.1 \\
\hline 7. & APB7 & 0.0 & 0.1 & 0.2 & 24. & APB24 & 0.0 & 0.2 & 0.3 \\
\hline 8. & APB8 & 0.0 & 0.0 & 0.1 & 25. & APB25 & 0.2 & 0.4 & 0.3 \\
\hline 9. & APB9 & 0.2 & 0.2 & 0.2 & 26. & APB26 & 0.6 & 0.8 & 1.2 \\
\hline 10. & APB10 & 0.0 & 0.1 & 0.1 & 27. & APB27 & 0.0 & 0.2 & 0.4 \\
\hline 11. & APB11 & 0.0 & 0.0 & 0.1 & 28. & APB28 & 0.3 & 0.6 & 0.9 \\
\hline 12. & APB12 & 0.2 & 0.4 & 0.4 & 29. & APB29 & 0.2 & 0.3 & 0.4 \\
\hline 13. & APB13 & 0.0 & 0.1 & 0.2 & 30. & APB30 & 0.0 & 0.2 & 0.2 \\
\hline 14. & APB 14 & 0.0 & 0.0 & 0.1 & 31. & APB31 & 0.2 & 0.2 & 0.4 \\
\hline 15. & APB15 & 0.0 & 0.0 & 0.1 & 32. & APB32 & 0.0 & 0.0 & 0.2 \\
\hline 16. & APB16 & 0.0 & 0.0 & 0.2 & 33. & APB33 & 0.2 & 0.2 & 0.3 \\
\hline 17. & APB17 & 0.0 & 0.1 & 0.1 & & & & & \\
\hline
\end{tabular}

Table.3 Data representing the different parameters during fermentation

\begin{tabular}{|c|c|c|c|c|c|c|c|c|c|c|}
\hline $\begin{array}{c}\text { Sr. } \\
\text { No. }\end{array}$ & Isolates & \multicolumn{3}{|c|}{ Biomass (O.D. 600) } & \multicolumn{3}{c|}{$\mathrm{pH}$} & \multicolumn{3}{c|}{$\begin{array}{c}\text { Crude enzyme activity } \\
\text { (Unit/ml) }\end{array}$} \\
\cline { 3 - 11 } & & $\begin{array}{c}24 \\
\text { hrs. }\end{array}$ & $\begin{array}{c}48 \\
\text { hrs. }\end{array}$ & $\begin{array}{c}72 \\
\text { hrs. }\end{array}$ & $\begin{array}{r}24 \\
\text { hrs. }\end{array}$ & $\begin{array}{r}48 \\
\text { hrs. }\end{array}$ & $\begin{array}{c}72 \\
\text { hrs. }\end{array}$ & $\begin{array}{c}24 \\
\text { hrs. }\end{array}$ & 48 hrs. & 72 hrs. \\
\hline 1 & APB1 & 0.90 & 1.20 & 1.28 & 7.5 & 7.8 & 8.0 & 0.40 & 0.52 & 1.58 \\
\hline 2 & APB2 & 0.98 & 1.32 & 1.40 & 7.4 & 7.7 & 7.9 & 0.48 & 0.55 & 1.08 \\
\hline 3 & APB26 & 1.50 & 1.84 & 2.42 & 7.8 & 8.2 & 8.9 & 2.20 & 3.50 & 3.78 \\
\hline 4 & APB28 & 0.80 & 0.95 & 1.55 & 7.3 & 7.5 & 7.8 & 0.35 & 0.49 & 0.80 \\
\hline
\end{tabular}

Table.4 Partial purification of L-asparaginase from isolate APB26

\begin{tabular}{|c|l|c|c|c|c|c|}
\hline $\begin{array}{c}\text { Sr. } \\
\text { No. }\end{array}$ & Purification step & $\begin{array}{c}\text { Total } \\
\text { enzyme } \\
\text { activity } \\
\text { (units/ml) }\end{array}$ & $\begin{array}{c}\text { Total } \\
\text { protein } \\
(\mathbf{m g} / \mathbf{m l})\end{array}$ & $\begin{array}{c}\text { Specific } \\
\text { activity } \\
\text { (units/mg) }\end{array}$ & $\begin{array}{c}\text { Relative } \\
\text { Purification } \\
\text { Fold }\end{array}$ & $\begin{array}{c}\text { Yield } \\
(\%)\end{array}$ \\
\hline 1 & Crude & 5.28 & 2.20 & 2.22 & 1.00 & 100 \\
\hline 2 & $\begin{array}{l}\text { Ammonium sulfate } \\
\text { precipitation }\end{array}$ & 4.72 & 1.82 & 2.59 & 1.16 & 89.3 \\
\hline 3 & $\begin{array}{l}\text { DEAE cellulose } \\
\text { chromatography }\end{array}$ & 3.50 & 0.98 & 3.57 & 1.60 & 66.3 \\
\hline
\end{tabular}


Table.5 Microbiological characteristics of APB26 isolate

\begin{tabular}{|c|c|c|c|c|c|}
\hline \multicolumn{6}{|c|}{ Morphological characters } \\
\hline \multicolumn{2}{|l|}{ Gram reaction } & \multicolumn{4}{|c|}{ Gram positive rods } \\
\hline \multicolumn{2}{|l|}{ Motility } & \multicolumn{4}{|c|}{ Motile } \\
\hline \multicolumn{2}{|l|}{ Capsule staining } & \multicolumn{4}{|c|}{ Non-capsulated } \\
\hline \multicolumn{2}{|l|}{ Spore staining } & \multicolumn{4}{|c|}{ Spore forming } \\
\hline \multicolumn{6}{|c|}{ Biochemical characters } \\
\hline \multicolumn{2}{|c|}{ Indole production } & + & \multicolumn{2}{|l|}{ Catalase } & + \\
\hline \multicolumn{2}{|l|}{ Methyl red test } & + & \multicolumn{2}{|l|}{ Oxidase } & + \\
\hline \multicolumn{2}{|c|}{ Voges-Proskauer's test } & - & \multicolumn{2}{|c|}{ Phenyl alanine deaminase } & - \\
\hline \multicolumn{2}{|c|}{ Citrate utilization } & + & \multicolumn{3}{|c|}{ Sugar utilization } \\
\hline \multicolumn{2}{|c|}{ Ammonia production } & + & \multicolumn{2}{|l|}{ Lactose } & + \\
\hline \multicolumn{2}{|c|}{ Nitrate reduction } & + & \multicolumn{2}{|l|}{ Maltose } & + \\
\hline \multicolumn{2}{|c|}{ Starch hydrolysis } & + & \multicolumn{2}{|l|}{ Sucrose } & + \\
\hline \multicolumn{2}{|c|}{ Casein hydrolysis } & + & \multicolumn{2}{|l|}{ Glucose } & + \\
\hline \multicolumn{2}{|c|}{ Gelatin hydrolysis } & - & \multicolumn{2}{|l|}{ Xylose } & + \\
\hline \multicolumn{2}{|l|}{ Urea hydrolysis } & - & \multicolumn{2}{|l|}{ Mannose } & + \\
\hline \multicolumn{2}{|c|}{ Blood haemolysis on blood agar } & + & \multicolumn{2}{|l|}{ Mannitol } & + \\
\hline \multicolumn{2}{|l|}{ Lipase } & - & \multicolumn{2}{|l|}{ Fructose } & + \\
\hline \multicolumn{6}{|c|}{ Cultural characters } \\
\hline Medium & \begin{tabular}{|l} 
Size and \\
Shape \\
\end{tabular} & Margin & Elevation & $\begin{array}{l}\text { Consistency } \\
\text { and Opacity }\end{array}$ & Pigmentation \\
\hline Nutrient agar & $\begin{array}{l}\text { Medium and } \\
\text { Round }\end{array}$ & Entire & Effused & $\begin{array}{l}\text { Smooth and } \\
\text { Opaque }\end{array}$ & Non pigmented \\
\hline $\begin{array}{l}\text { MacConkey's } \\
\text { agar }\end{array}$ & $\begin{array}{l}\text { Medium and } \\
\text { Round }\end{array}$ & Entire & Effused & $\begin{array}{l}\text { Smooth and } \\
\text { Opaque }\end{array}$ & $\begin{array}{l}\text { Lactose non- } \\
\text { fermenter }\end{array}$ \\
\hline
\end{tabular}

Fig.1 Effect of $\mathrm{pH}$ and temperature on production of L-asparaginase from APB 26
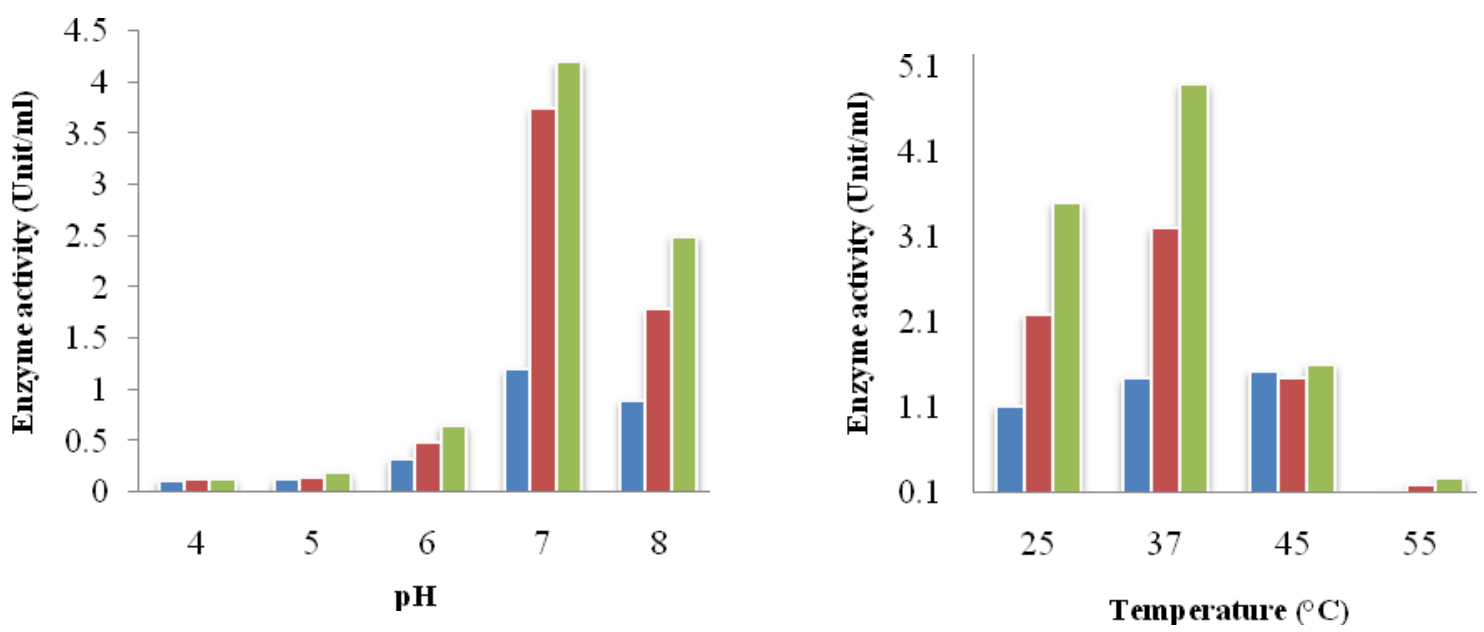

$24 \mathrm{hrs} \quad 48 \mathrm{hrs} \quad 72 \mathrm{hrs}$ 
Results of ammonium sulfate precipitation showed that specific activity of enzyme was increased from 2.22 to 2.59 units/mg with 1.16 purification fold. Further, DEAE cellulose chromatography results showed 3.57 units/mg specific activity of enzyme with 1.60 relative purification fold and $0.98 \mathrm{mg} / \mathrm{ml}$ protein concentration (Table 4).

\section{Microbiological characteristics of isolate}

Preliminary morphological, biochemical and cultural characteristics of APB 26 isolate was performed and presented in table 5.

Data showed that APB26 isolate was motile, gram positive rods, spore forming and noncapsulated bacteria. On nutrient media colony was found to be round with medium size with entire margin and effused elevation. It was non-pigmented, opaque and lactose nonfermenter on MacConkey's agar medium. Beta haemolysis was observed on blood agar plate within 24 hrs. Biochemical characters showed that APB 26 was able to utilize lactose, maltose, sucrose, glucose, xylose, mannose, mannitol and fructose; given positive results for indole production, methyl red test, citrate utilization, ammonia production, citrate utilization, hydrolysis of starch and casein, catalase and oxidase enzymes; while negative for VogesProskaurer's test, lipase, phenylalanine deaminase, gelatin and urea hydrolysis.

Earlier investigation was carried out either using rhizosphere soil of farms/gardens or mangrove systems (Moorthy et al., 2010; Bhat et al., 2015) for isolation of Lasparaginase producing microorganisms. Rajguru and Deshmukh (2016) had used different ecosystem to get potential Lasparaginase producing microbes. In present study, organic/natural soil and industrially contaminated soil samples were collected to screen the potential L-asparaginase producing bacteria. Total 120 bacterial isolates were isolated from seven different locations as described earlier. Among them, 33 strains were producing pink zone on modified M-9 medium indicated L-asparaginase production during primary screening (Gulati et al., 1997). Based on zone of index four bacterial isolates (APB1, APB2, APB26 and APB28) were used for fermentation study. Further, it was observed that APB1 and APB2 was isolated from sugarcane rhizosphere while, APB26 and APB28 from poultry farm soil. The four selected strains showed gradually increased biomass, $\mathrm{pH}$ and ammonia production within $76 \mathrm{hrs}$. Increased biomass indicated ability of microbes to utilize nutrients of the medium, which used for their growth. According to De Jong (1972) and Shafiq et al., (2013) Lasparaginase production associated with increased $\mathrm{pH}$ due to accumulation of ammonia as end product (De Jong, 1972; Shafiq et al., 2013). Based on this, rate of hydrolysis of L-asparaginase was calculated by measuring the release of ammonia by Nessler's method. Data showed that among four strains APB26 (3.78 unit/ml) had given maximum enzyme activity than APB1 (1.58 unit $/ \mathrm{ml})$, APB2 (1.08 unit $/ \mathrm{ml})$ and APB28 (0.80 unit $/ \mathrm{ml})$ within $72 \mathrm{hrs}$. Thus, APB26 was used for further study. Varma et al., (2016) had studied the effect of different $\mathrm{pH}$ and temperature to get maximum Lasparaginase production. Thus, to optimize the $\mathrm{pH}$ and temperature of L-asparaginase production, APB26 subjected with different $\mathrm{pH} \quad(4.0, \quad 5.0, \quad 6.0, \quad 7.0$ and 8.0) and temperatures $\left(25^{\circ} \mathrm{C}, 37^{\circ} \mathrm{C}, 45^{\circ} \mathrm{C}\right.$ and $\left.55^{\circ} \mathrm{C}\right)$. Maximum crude enzyme activity was found with $\mathrm{pH} 7.0$ at $37^{\circ} \mathrm{C}$. Further, partial purification of L-asparaginase from APB26 was performed using ammonium sulfate precipitation and DEAE cellulose chromatography. Increased specific activity with purification fold observed with both ammonium sulfate $(2.59 \mathrm{unit} / \mathrm{ml}$ and 1.16 purification fold) and DEAE cellulose chromatography $(3.57 \mathrm{unit} / \mathrm{ml}$ and 1.60 
purification fold). Emmanuel et al., (2015) had observed similar kind of L-asparaginase activity from Hedgehog serum. Further, APB26 isolate was characterized based on its morphological, cultural and biochemical test. Based on results, APB26 isolate was gram positive rods, spore forming and noncapsulated bacteria. Positive results for catalase and oxidase indicated that the isolate was aerobic or facultative anaerobic bacteria (Ahmed, 2012; Acharya, 2012). According to these results, APB26 was able to utilize wide range of carbon source in form of glucose, lactose, sucrose, maltose, mannitol, mannose, fructose and xylose while unable to utilized gelatin. Further, citrate used as a sole carbon and nitrogen source by the isolate. Positive results of starch and casein utilization indicated that it can able to produce amylase and caseinase enzymes. Indole and methyl red positive test indicated fermentative utilization of glucose. APB26 was also able to produce ammonia and nitrate but unable to utilize urea and phenylalanine as a nitrogen source. Beta haemolysis on blood agar indicated haemolysins (erythrocyte lysing enzymes) by APB26. From the above characterization and according to the Bergey's Manual determinative bacteriology the potent APB26 strain might belong to Bacillus genus. However, further molecular as well as microbiological studies require for complete identification of the isolate.

\section{References}

Abbas, A.A., Sabbah, M. A. and Kathum, O. A. 2010. Partial purification and cytotoxic activity of L-asparaginase isolated from Escherichia coli. Iraq. J. Sci., 51(2): 290-294.

Acharya, T., 2012. Microbiology: Microbeonline available at http://microbeonline.com/oxidase-testprinciple-procedure.

Agarwal, A., Kumar, S. and Veeranki, V. D. 2011. Effect of chemical and physical parameters on the production of Lasparaginase from a newly isolated Serratia marcescens SK-07. Lett. Appl. Microbiol., 52: 307-313.

Ahmed, B., 2012. Medicalopedia availbale at http://www.medicalopedia.org/3149/list -of-catalase-positive-microorganisms.

Bhat, M.R., Nair, J. S. and Marar, T. 2015. Isolation and identification of 1asparaginase producing salinicoccus $\mathrm{sp}$. MKJ 997975 from soil microbial flora. Int. J. Pharma. Sci. Res., 6(8): 35993605.

Broome, J.D., 1968. Factors which may influence the effectiveness of $\mathrm{L}$ asparaginases as tumor inhibitors. $\mathrm{Br} . \mathrm{J}$. Cancer., 22: 595-602.

Clementi, A., 1922. Presence of LAsparaginase in animals and its significance. Arch. Int. Physiol., 19: 369-398.

De Jong, P., 1972. L-asparaginase production by Streptomyces griseus. Appl. Micro., 23: 1163-1134.

Dhevagi, P., and Poorani, E. 2006. Isolation and characterization of L-asparaginase from marine actinomycetes. $J$. of Biotech. 5: 514-520.

Emmanuell, E., Nzelibe, H. C. and Onyike, E. 2015. Isolation, partial purification and characterization of L-asparaginase from hedgehog serum. J. Microb. Biochem. Technol., 7(6): 404-409.

Gulati, R., Saxena, R.K. and Gupta, R. 1997. A rapid plate assay for screening of $\mathrm{L}$ asparaginase producing microorganisms. Lett. Appl. Micro., 24: 23-26.

Jimat, D.N., Intan, B. F. M., Azlin, S. A. and Zaki, Z. 2015. Isolation and characterization of thermophilic bacteria producing L-asparaginase from malaysia hotspring and enzyme activity using different carbon and nitrogen sources. J. Appl. Sci. Agri., 10(5): 6977. 
Kidd, J.G., 1953. Regression of transplanted lymphomas induced in vivo by means of normal guinea pig serum. I. course of transplanted cancers of various kinds in mice and rats given guinea pig serum, horse serum or rabbit serum. J. Exp. Med., 98: 565-582.

Lowry, O.H., Rosebrough, N. J., Farr, A. L. and Randall, R. J. 1951. Protein measurement With the Folin-Phenol reagent. J. Biol. Chem., 193: 265-275.

MacFaddin, J.F., 2000. Biochemical tests for identification of medical bacteria. Williams and Wilkins, London.

Moorthy, V., Ramalingam, A., Sumantha, A. and Shankaranaya, R. T. 2010. Production, purification and characterization of extracellular Lasparaginase from a soil isolate of Bacillus sp. Afri. J. Micro. Res., 4(18): 1862-1867.

Oettgen, H.F., Old, L. J., Boyse, E. A. Campbell, H. A., and Philips, F. S. 1967. Inhibition of leukemias in man by L-asparaginase. Cancer Res., 27: 26192631.

Pradhan, B., Dash, S. K. and Sabuj, S. 2013. Screening and characterization of extracelluar L-asparaginase producing Bacillus subtilis strain hswx 88, isolated from taptapani hotspring of Odisha, India. Asian Pac. J. Trop. Biomed., 3(12): 936-941.

Rajguru, S.A., and Deshmukh, P. V. 2016. Isolation and screening of 1 asparaginase producing bacteria from aquatic and terrestrial habitats in thane district, M.S, India. World J. Pharma.
Pharmaceu. Sci., 5(9): 1807-1817.

Shafiq, S.A., Muslim, S.N. and Khudhair, M. F. 2013. Isolation and culture of Acinetobacter baumannii. $W . \quad J$. Pharmace. Res., 2(5): 1254-1269.

Sunitha, M., Ellaiah, P. and Bhavani, R. 2010. Screening and optimization of nutrients for $\mathrm{L}$ asparaginase production by Bacillus cereus MNTG-7 in SmF by plackett-burmann design. Afr. J. Microbiol., 4(4): 297-303.

Thenmozhi, C., Sankar, R., Karuppiah, V. and Sampathkumar P. 2011. L-asparaginase production by mangrove derived Bacillus cereus MAB5: optimization by response surface methodology. Asian Pac. J. Trop. Med., 4(6): 486-491.

Varma, R.A., Kanapala, S., Naga, S. B. V., Bodaiah, B. and Poda, S. 2016. Partial purification, characterization and optimization of anti-leukemic enzyme L-asparaginase from mangrove soil actinobacteria. J. Pharma. Res., 10(7): 502-511.

Warangkar, S.C., and Khobragade, C. N. 2010. Purification, characterization, and effect of thiol compounds on activity of the Erwinia carotovora L-asparaginase. Enzy. Res., pp: 1-10.

Worthington, K., 2007. L-asparaginase Assay: Worthington Biochemical Corp, available at http://www.worthingtonbiochem.com/aspr/assay.

Yellin, T.O., and Wriston, J. C. 1966. Purification and properties of guinea pig serum asparaginase. Biochem. 5: 16051612.

\section{How to cite this article:}

Savani, A.V. and Parmar, P.R. 2017. Screening and Partial Purification of L-Asparaginase from the Bacteria Isolated from Soil Samples. Int.J.Curr.Microbiol.App.Sci. 6(9): 784-792. doi: https://doi.org/10.20546/ijcmas.2017.609.097 